\title{
Beta cell mass in diabetes: a realistic therapeutic target?
}

\author{
J. J. Meier
}

Received: 25 September 2007 / Accepted: 19 December 2007 /Published online: 4 March 2008

(C) Springer-Verlag 2008

\begin{abstract}
Beta cell deficiency underlies both type 1 and type 2 diabetes, and restoration or replacement of beta cell function is therefore the logical long-term solution to therapy. This review sets out to describe the defects in beta cell mass and function in both forms of diabetes, summarises current understanding of the underlying causes of beta cell death, and the methodological limitations of determining beta cell mass in vivo. Finally, the potential effects of current and future treatment regimens on beta cell mass and turnover are considered.
\end{abstract}

Keywords Apoptosis $\cdot$ Beta cell imaging $\cdot$ Beta cell turnover - Beta cell rest - GLP-1 - Proliferation .

Sulfonylureas · Type 1 diabetes · Type 2 diabetes

$\begin{array}{ll}\text { Abbreviations } \\ \text { DPP-4 } & \text { dipeptidylpeptidase } 4 \\ \text { ER } & \text { endoplasmatic reticulum } \\ \text { GLP-1 } & \text { glucagon-like peptide } 1 \\ \text { MRI } & \text { magnetic resonance imaging } \\ \text { VMAT2 } & \text { vesicular amine transporter } 2\end{array}$

\section{Introduction}

While it has long been held that type 1 diabetes results from an irreversible loss of beta cells, and that type 2 diabetes is primarily caused by impaired insulin action, there is now

\footnotetext{
J. J. Meier $(\bowtie)$

Department of Medicine I, St Josef-Hospital,

Ruhr-University of Bochum,

Gudrunstr. 56,

44791 Bochum, Germany

e-mail: juris.meier@rub.de
}

increasing evidence linking both types of diabetes to defects in beta cell mass and insulin secretion. Furthermore, the former dogma that postnatal beta cells are irreversibly postmitotic and thus not capable of replicating during adult life has been challenged over the past years. These advances offer the potential of targeting beta cell regeneration as a future treatment of diabetes. In this review we will describe the defects in beta cell mass and function in both type 1 and type 2 diabetes, summarise the underlying causes of beta cell death, and evaluate the methodological limitations of determining beta cell mass in vivo. Finally, we will discuss the potential effects of current and future glucose-lowering treatment regimens on beta cell mass and turnover in patients with diabetes.

\section{Beta cell mass in diabetes}

Both type 1 and type 2 diabetes are characterised by deficits in beta cell mass $(\sim 99 \%$ deficit in long-standing type 1 diabetes $[1,2], \sim 65 \%$ deficit in long-standing type 2 diabetes [3]; Fig. 1). While there is little doubt regarding the importance of increased autoimmune-mediated beta cell death in type 1 diabetes [2], recent studies suggest that the frequency of beta cell apoptosis is also significantly increased in type 2 diabetes [3], although other factors, such as the failure of beta cell mass to expand adequately in response to rising secretory demands, cannot be excluded. This loss of beta cells in both types of diabetes implies that restoration of endogenous insulin secretion and normalisation of hyperglycaemia in such patients might be accomplished through the replacement or regeneration of islet cells [4]. Indeed, hyperglycaemia in both types of diabetes is reversed by pancreas transplantation [5], and intraportal transplantation of isolated islets temporarily 


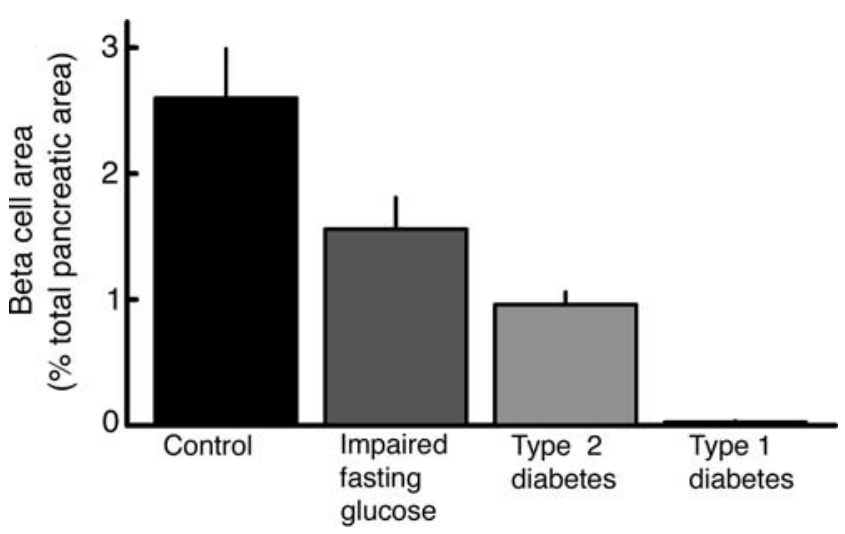

Fig. 1 Fractional beta cell area in the pancreas of obese non-diabetic individuals, individuals with impaired fasting glucose, patients with type 2 diabetes and patients with type 1 diabetes. Modified from [3] and [2]

restores glucose control [6]. Unfortunately, replacement of beta cell mass by islet or pancreas transplantation is associated with both surgical morbidity and the adverse effects of chronic immunosuppression [7]. Moreover, there is an insufficient supply of pancreases available for the increasing number of people with diabetes, thus preventing the widespread implementation of this intervention [7]. There is therefore a need for alternative approaches for restoring functional beta cell mass in patients with diabetes.

Both type 1 and type 2 diabetes are characterised by a significant deficit in beta cell mass, presumably caused by beta cell apoptosis.

\section{Type 2 diabetes}

Type 2 diabetes is characterised by a combination of insulin resistance and beta cell dysfunction [8,9]. The risk of developing type 2 diabetes rises exponentially with increasing obesity and insulin resistance. Temporary restoration of glucose control in patients with type 2 diabetes is often achieved through weight loss and increased physical activity. These observations have led to the misconception that insulin resistance is the primary defect underlying the development of type 2 diabetes [9]; however, a number of points argue against such reasoning. First, even though the risk of developing diabetes is increased in obesity, $\sim 80 \%$ of obese individuals remain non-diabetic [10]. Likewise, even severe insulin resistance, such as that induced by glucocorticoid therapy or pregnancy, leads to the development of diabetes only in small percentage of patients. Second, the maximal insulin secretory responses to intravenous glucose, arginine and other secretagogues are greatly diminished in patients with type 2 diabetes [11-13]. In particular, the pulsatile pattern of prehepatic insulin release is abnormal in type 2 diabetes. Defects in insulin secretion have also been described in certain populations at high risk of developing type 2 diabetes (e.g. individuals with impaired glucose tolerance, first-degree relatives of diabetic patients), even though the interpretation of some of these studies is hampered by the potential dampening of insulin responses by the different baseline glucose levels [14]. Based on such crosssectional studies, defects in insulin secretion appear to even precede the development of insulin resistance [14]. Third, insulin resistance is found not only in type 2 diabetes, but also in type 1 diabetes, presumably as a consequence of impaired insulin secretion [15]. Fourth, as mentioned above, there is a beta cell deficit in patients with long-standing type 2 diabetes ( $\sim 65 \%$ beta cell loss), and this is also seen in individuals with impaired fasting glucose $(\sim 50 \%$ beta cell loss; Fig. 1) [3]. Fifth, a similar $50 \%$ experimental or surgical reduction of beta cell mass leads to the development of diabetes in various animal models as well as in humans [16-18]. Sixth, the typical metabolic defects of type 2 diabetes (impaired insulin secretion, hepatic insulin resistance, hyperglucagonaemia) can be mimicked in animals with a progressive beta cell loss reminiscent of that in patients with type 2 diabetes [19]. Seventh, despite the overt presence of insulin resistance, hyperglycaemia in type 2 diabetes can be offset by restoration of beta cell mass through pancreas transplantation $[20,21]$. Taken together, these studies support the postulate that the clinical syndrome of hyperglycaemia develops in both type 1 and 2 diabetes in large part as a consequence of a deficit in beta cell mass.

Potential causes of beta cell loss in type 2 diabetes The beta cell loss in type 2 diabetes is accompanied by a marked increase in beta cell apoptosis, as shown in human pancreas autopsy specimens and in isolated islets [3, 22]. Several mechanisms have been proposed as triggers for the increased beta cell loss in type 2 diabetes (Fig. 2). These include high concentrations of glucose ('glucose toxicity') [23] and NEFA ('lipotoxicity') [23, 24]. However, to a large extent, the studies in this field have been carried out in vitro and in rodent models and are therefore not generalisable to humans. In fact, in humans, prolonged exposure to high lipid concentrations has even resulted in an increased insulin secretory response [25]. Other potential factors leading to beta cell death in type 2 diabetes are toxic oligomers of human islet amyloid polypeptide [26], reactive oxygen species [27], endoplasmatic reticulum (ER) stress [28], and inflammatory cytokines such as IL-1 $\beta$ [29]. In reality, the clinical syndrome of type 2 diabetes is likely the consequence of more than one cause, and loss of beta cells probably involves more than one mechanism. Based on cross-sectional studies, normoglycaemia can be maintained until $\sim 50 \%$ of beta cell mass is lost [30], with greater losses typically resulting in deterioration of glucose control [3, 17, 30]. However, the wide range of beta cell mass in non-diabetic individuals suggests that the timing of diabetes onset at a given degree 
Fig. 2 Different factors inducing beta cell apoptosis (black) in type 2 diabetes (left side), type 1 diabetes (right side) or both types of diabetes (middle). Blue boxes show drugs with a potential to preserve beta cell mass in patients of diabetes through inhibition of these factors. hIAPP, human islet amyloid polypeptide
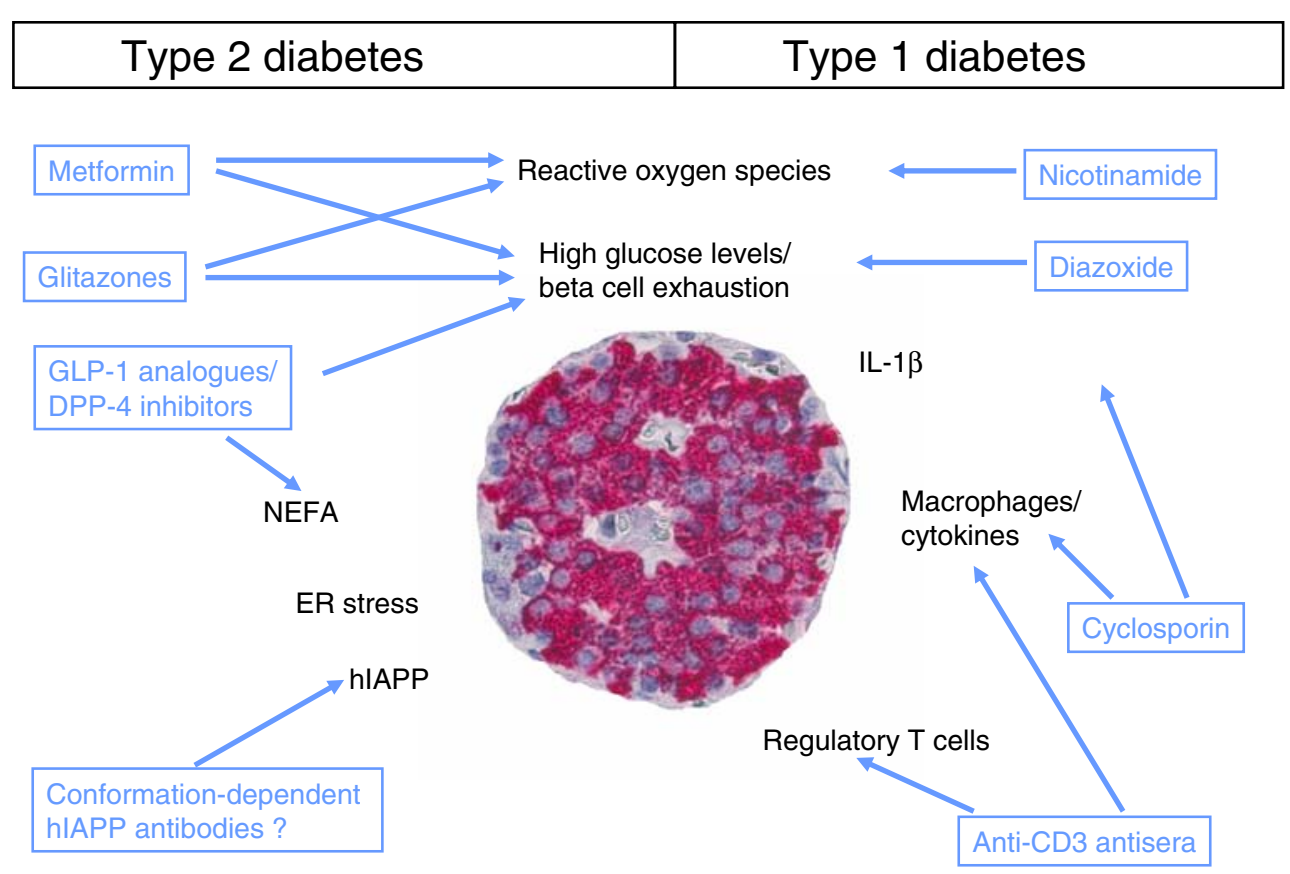

of beta cell loss varies from person to person and is influenced by other factors such as insulin sensitivity [3].

\section{Type 1 diabetes}

In type 1 diabetes, beta cell loss occurs as a consequence of immune-mediated beta cell destruction [1, 2, 31] (Fig. 2), although the trigger(s) for this process remains unknown. This depletion within the islet is beta cell-specific, perhaps mediated through insulin serving as an antigen attracting auto-reactive T lymphocytes and macrophages. Similar to the pathogenesis of type 2 diabetes, the destruction of beta cells in patients with type 1 diabetes seems to precede the clinical manifestation of the disease, and impaired insulin secretion can be detected several years prior to the onset of hyperglycaemia [32]. Based on histological studies of pancreas specimens from patients with new-onset type 1 diabetes, beta cell mass is reduced by $\sim 80-90 \%$ at this time [1, 33-35]. Interestingly, the degree of beta cell dysfunction at this time often exceeds the percentage beta cell loss [3638], suggesting additional functional impairment in insulin secretion in these patients. Both beta cell mass and function further decline with increasing diabetes duration [33, 37, 39], but preserved C-peptide responses have been reported even after several years of type 1 diabetes $[40,41]$. While it has long been held that the beta cell loss in type 1 diabetes is a finite and irreversible process, there is now evidence from several lines of research that some beta cell regeneration may occur even in patients with long-term type 1 diabetes [2]. Thus, even though beta cell mass is markedly diminished in the pancreas of patients with long-standing type 1 diabetes, some beta cells can be detected several decades after the onset the disease [1, 2]. These cells are often associated with $\mathrm{T}$ lymphocytes and macrophages, and have an increased frequency of apoptosis, implying that concomitant beta cell formation must be occurring even after several years of type 1 diabetes [2]. This hypothesis has been supported by reports of restoration of beta cell mass after the onset of hyperglycaemia in NOD mice [42], and of a marked increase in beta cell replication at the time of diabetes onset in mice and in humans [36, 38].

The potential for restoration of beta cell mass

The beta cell deficit in both type 1 and type 2 diabetes provides a rationale for novel therapeutic strategies aimed at restoring (or at least preventing further loss of) beta cell mass. In fact, enhancement of endogenous insulin secretion may theoretically provide several advantages over the administration of exogenous insulin: (1) the kinetics of endogenous insulin secretion are much faster than those of subcutaneously administered insulin [43, 44]; (2) under physiological circumstances, insulin is secreted in distinct pulses occurring at $~ 4-5$ min intervals [45], and endogenous insulin secretion is regulated in a strictly glucose-dependent manner [46]; (3) alpha cell secretion is controlled by the pulsatile release of insulin from islet beta cells [18, 47]; (4) endogenous pulsatile insulin secretion has a direct effect on hepatic glucose metabolism, whereas exogenous insulin replacement primarily acts on peripheral insulin-sensitive tissues. The hypothetical consequences that might arise from restoration of beta cell mass for glucose control in patients with diabetes have been summarised in Fig. 3. 
Fig. 3 Hypothetical diagram illustrating the potential consequences of beta cell regeneration for glucose metabolism. Theoretically, beta cell regeneration will lead to restoration of beta cell mass, which in turn will restore a physiological, pulsatile pattern of insulin secretion. Improved insulin secretion will subsequently lead to intra-islet suppression of alpha cell secretion and, in concert with lower glucagon levels, suppress the excessive hepatic glucose production. Finally, insulin action in muscle and adipose tissue will improve secondary to increased insulin secretion and reduced hepatic glucose output. Collectively, these changes may restore normoglycaemia in patients with diabetes

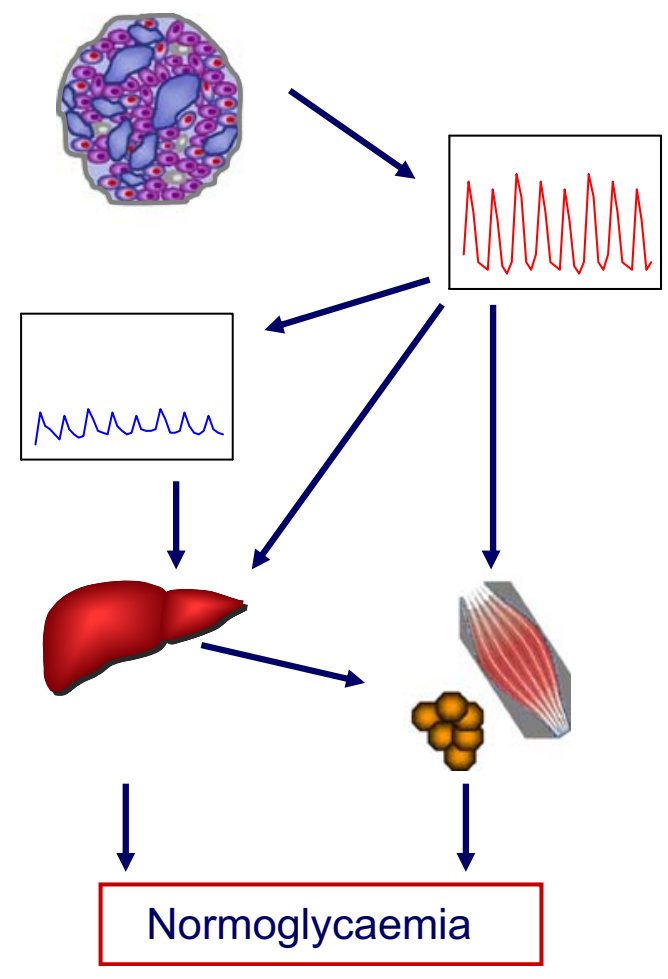

Restoration of beta cell mass

Restoration of (pulsatile) insulin secretion

Suppression of glucagon secretion

Reduction of hepatic glucose
production

Improvement in peripheral insulin action
Strategies for beta cell regeneration

Embryonic stem cells One potential way of replenishing beta cell mass is the ex vivo generation of insulin-secreting cells from embryonic stem cells through directed differentiation [4]. Indeed, this field has advanced over recent years, in particular as a result of the development of more specific incubation regimens, allowing for a coordinated differentiation of human embryonic stem cells through different stages resembling definitive endoderm, gut tube endoderm, pancreatic endoderm and endocrine precursor cells [48]. Such human embryonic stem cell-derived preparations have been shown to release insulin upon challenge by different secretagogues, but reported to be particularly unresponsive to glucose stimulation [48]. In addition to this lack of glucose responsiveness, ethical hurdles associated with the generation of insulin-secreting cells from human embryos complicate the further development of this approach. Moreover, under physiological conditions, beta cells are embedded into the complex structure of the islet, which allows for the multi-modal control of insulin secretion through neural (e.g. sympathetic nerve fibres) [49], endocrine (e.g. intraislet glucagon) [18, 47, 50] and paracrine (e.g. somatostatin) [50] mechanisms. Given the technical difficulties associated with the generation of a single cell type, it seems unlikely that the complex organisation of the pancreatic islet can be replicated through targeted differentiation of embryonic stem cells. On the other hand, the importance of non-beta cells for glucose control following islet transplantation has been challenged by recent experiments in rats [51]. Finally, it is as yet impossible to control the proliferative activity of such cells, which poses a risk for tumour formation [4].

New beta cells derived from embryonic stem cells may be an interesting future strategy for the treatment of diabetes, but this approach appears to be far from ready for clinical application.

Extrapancreatic stem cells Not only human embryonic stem cells, but also mature cells of different origin, including liver, spleen, bone marrow and exocrine pancreas, have been reported to generate insulin-producing cells [4]. However, the overall plasticity of such differentiated cells appears to be even lower than that of human embryonic stem cells, and such cells typically lack other important beta cell components required for a coordinated mode of insulin secretion, such as glucokinase and GLUT-2.

Beta cell replication and islet neogenesis An alternative strategy for the restoration of beta cell mass in patients with diabetes is to foster beta cell regeneration from endogenous sources [4]. Some evidence suggests that beta cell mass is dynamic and capable of undergoing adaptive changes in response to different secretory demands [52]. In humans, beta cell mass increases by $\sim 50 \%$ in obesity [3], and both insulin secretion and beta cell mass have been shown to increase in pregnant women [53, 54]. Likewise, beta cell mass in rodents increases by $\sim 2.5$-fold towards the end of pregnancy, and is rapidly decreased through increased apoptosis and reduced replication postpartum $[52,55,56]$. 
There is ongoing debate as to the potential origin of new beta cells in adults, and two major pathways have been proposed. On the one hand, replication of pre-existing beta cells in the pancreas has been convincingly demonstrated in adult mice $[57,58]$, rats $[59,60]$ and humans $[3,36,61,62]$ (Fig. 4), and recent lineage tracing studies indicated that new beta cell formation in postnatal mice exclusively results from the replication of existing beta cells [57]. On the other hand, the close association between exocrine ducts and beta cells has been interpreted as evidence that beta cells might also arise from stem cells residing in the ductal epithelium [63, 64] (Fig. 4). However, since it is as yet impossible to determine the exact origin of mature beta cells in cross-sectional studies, the importance of this pathway has not been convincingly proven. In the absence of a reliable beta cell precursor marker, the percentage of ductal cells producing insulin has often been used as a surrogate marker for this ductal neogenesis [65], and significant increases have been described in rodents after partial pancreatectomy $[63,66]$ and after prolonged hyperglycaemia or glucagon-like peptide 1 (GLP-1) treatment $[67,68]$. Beta cells have been observed to be colocalised with exocrine ducts in human embryonic tissue [69] and in adult human pancreas specimens from individuals with or without diabetes [2, 3] (Fig. 4). Despite this obvious association between exocrine ducts and beta cells, the possibility remains that this phenomenon merely represents a residuum of fetal pancreas development and that the observed increases in the number of these insulin-positive cells within or adjacent to exocrine ducts relate more to a general expansion of beta cell mass, without a causal relationship to the ductal epithelium.

While the presence and quantitative significance of new beta cell formation from exocrine ducts remains to be proven, there is little doubt that beta cell replication continues over a lifetime (see above). However, the overall frequency of beta cell replication is extremely low in the adult pancreas, thereby complicating its quantitative assessment [59]. The rate of beta cell replication in adult rats was recently estimated to be $\sim 0.07 \%$ per day using BrdU labelling [59], but subsequent studies have cautioned against the use of this technique, since prolonged infusion of BrdU may independently suppress cell proliferation [70].

Despite the slow rate of beta cell turnover under normal steady-state conditions, there appears to be a remarkable capacity for increased proliferation in situations of high secretory demand. In rodents, beta cell replication increases by approximately five- to tenfold after partial pancreatectomy, during pregnancy, during chronic glucose infusion and after treatment with GLP-1 analogues [63, 66], thereby illustrating the remarkable plasticity of the endocrine pancreas in rodents. In humans, the overall capacity for beta cell replication is much lower than in rodents, and very few replicating beta cells (one cell in $\sim 50$ islets of $\sim 100$ beta cells each per cross-section) can be found in adult human pancreas [3]. There is, however, a capacity for increased beta cell replication in humans. Beta cell replication has been reported to be more than ten times higher in human pancreas adjacent to gastrin-producing tumours [62] and in the pancreas of a patient presenting with the recent-onset type 1 diabetes [36].

The different turnover rates of beta cells in rodents and in humans have important implications for interpreting studies designed to replenish beta cell mass.

A number of recent studies have suggested that human beta cells maintain some capacity for regeneration even very late in life.

\section{Detection of beta cell mass}

Determination of the success of therapeutic strategies designed to enhance beta cell regeneration requires reliable methods for the assessment of beta cell mass. In animal models, beta cell mass can be easily calculated as the product
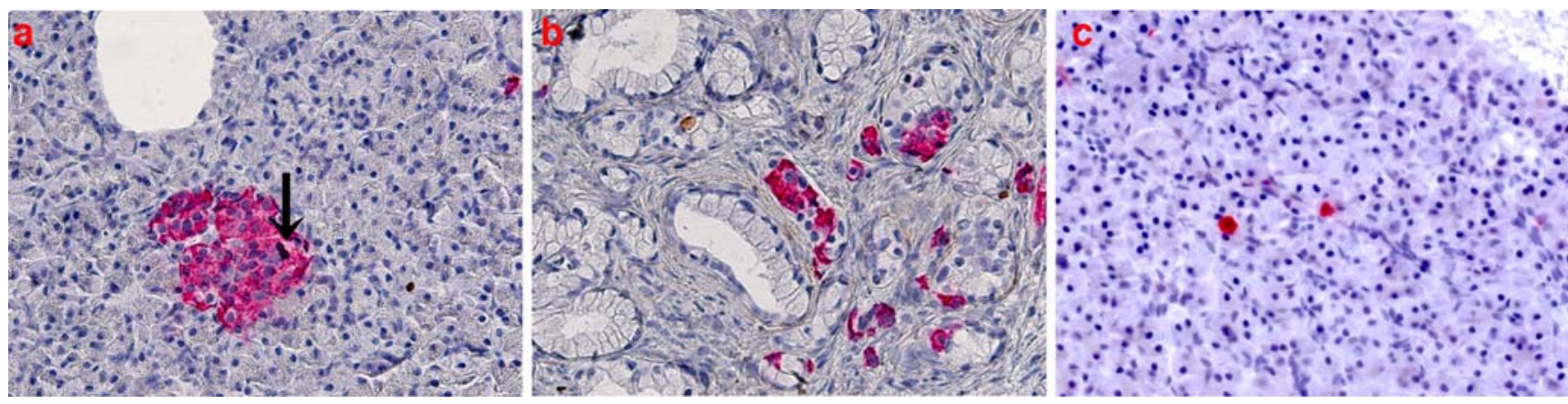

Fig. 4 Potential sources of new beta cell formation in adult human pancreas. Pancreatic sections were stained for insulin (red) and Ki67 (brown) and imaged at $\times 400$ magnification. a A pair of replicating beta cells positive for Ki67 (arrow). b Multiple beta cells within or adjacent to exocrine ducts. This finding has often been interpreted as evidence of new islet formation from ductal progenitor cells. c Two single beta cells in the exocrine parenchyma. Beta cells are often seen scattered throughout this tissue, a finding often interpreted as indicating transdifferentiation of exocrine cells into beta cells 
of pancreatic weight and the fractional beta cell area in crosssections from different regions of the pancreas [19, 58]. However, in light of the obvious inaccessibility of the human pancreas for repeated biopsy sampling, non-invasive procedures are warranted to quantify beta cell mass in vivo. Two different approaches have been used to determine the functional beta cell mass in living humans, described below.

Imaging strategies to determine beta cell mass

While the volume of endocrine organs such as the thyroid gland or adrenal gland can be calculated with a reasonable accuracy using common imaging techniques such as ultrasonography, computed tomography or magnetic resonance imaging (MRI), the scattered distribution and relatively small size $(\sim 200 \mathrm{~m}$ in diameter) of islets have so far hampered the reliable quantification of beta cell mass. Furthermore, the differences in density and echogeneity between exocrine and endocrine pancreatic tissue are relatively minor. Alternative approaches have relied on the specific labelling of beta cells using enzymes, cell receptors or surface structures that are predominantly or exclusively expressed on beta cells. Tags such as these can be detected by positron emission spectroscopy, MRI, or single photon emission computed tomography. However, since the beta cells occupy only $\sim 1-2 \%$ of the total pancreatic mass, any putative beta cell marker would be required to be at least 100:1 times more specific for beta cells than exocrine cells to give a labelling specificity of $50 \%$. To date, a number of different beta cell structures, including GLP-1 receptors, sulfonylurea receptors, vesicular amine transporter 2 (VMAT2) and gangliosides, have been used as targets for these labels. In addition, the IC2 antibody and antibodies directed against D-mannoheptulose and alloxan have been used because of their specific uptake by, or binding to, pancreatic beta cells. These studies have recently been summarised elsewhere [71]. However, to date, none of these markers has provided approximations of beta cell mass with sufficient sensitivity and specificity to justify their routine application in humans. Ongoing clinical trials are using VMAT2 as a surrogate marker of insulin production and the radioligand ${ }^{11} \mathrm{C}$-labelled dihydrotetrabenazine for the determination of beta cell mass in type 1 diabetic patients and controls. The final results of these trials are awaited.

Functional assessment of beta cell mass In the absence of a reliable imaging test to determine beta cell mass in humans in vivo, functional tests of insulin secretion have been applied. These tests are based on the assumption that the amount of insulin secreted in response to a secretagogue is proportional to the number of beta cells present in the pancreas. However, some theoretical caveats should be kept in mind with respect to the interpretation of such tests.
Insulin secretion may well change independently from beta cell mass. In fact, insulin secretion in obese individuals can be increased by a factor of five to ten [72], whereas beta cell mass has been shown to be only $\sim 50 \%$ higher in obese compared with lean individuals [3]. In line with this, a linear relationship has been observed between the mean nuclear diameter of beta cells and BMI, suggesting that the transcriptional activity of beta cells increases with higher insulin demands [61]. Furthermore, glucose-induced insulin secretion is subject to considerable day to day variation, and can be modulated to a large extent by pharmacological interventions, such as an overnight infusion of a GLP-1 analogue [73], temporary inhibition of insulin secretion [74] or prolonged glucose normalisation by the administration of exogenous insulin [75]. Most likely, these differences relate to differences in beta cell granule content, which determines subsequent insulin secretory responses. The second potential caveat relates to the different volumes of distribution between lean and obese individuals - the secretion of a certain number of insulin molecules in an obese individual with a large plasma volume will produce a lower plasma concentration than the secretion of the same number of molecules in a lean individual. Finally, differences in hepatic insulin clearance may alter systemic insulin levels $[72,76]$.

Despite the theoretical concerns, indirect testing of beta cell function currently represents the most reliable method of estimating beta cell mass in humans. The relationship between different indices derived from metabolic tests and the actual beta cell mass has recently been summarised elsewhere [77]. Generally, the closest correlation with beta cell mass has been obtained for arginine-induced insulin secretion and for glucose potentiation of arginine-induced insulin secretion ( $70 \%$ accuracy) $[78,79]$. It is also important to note that the assessment of glucose-induced insulin secretion will only provide reliable results when individuals are tested at similar glucose concentrations [12].

Given the lack of reliable routine methods to determine beta cell mass in humans in vivo, functional tests of insulin secretion may be a suitable alternative.

\section{Therapeutic strategies to maintain or restore beta cell mass in diabetes}

As a result of the growing interest in beta cell regeneration as a potential cure for diabetes, a number of different treatment strategies aimed at increasing beta cell mass have been evaluated. Owing to the limitations of directly quantifying beta cell mass in humans in vivo, different surrogates for beta cell regeneration have been used. These include (1) 
inhibition of beta cell apoptosis and/or stimulation of beta cell regeneration in beta cell lines and/or isolated (human) islets in vitro; (2) increasing beta cell mass in animal models (primarily rats and mice) in vivo; and (3) functional improvements (or at least preservation) of insulin secretion in long-term studies in patients with diabetes in vivo. The effects of various current and future pharmacotherapies for type 1 and type 2 diabetes on beta cell mass and turnover at these experimental levels have been summarised in the Table 1.

Importance of beta cell rest and exhaustion for diabetes therapy

When evaluating the effects of glucose-lowering treatment regimens on beta cell turnover, one key aspect determining the fate of the beta cells may be the individual's demand for insulin secretion. There is some evidence from in vitro studies that constant stimulation of insulin secretion by either prolonged high glucose exposure or sulfonylurea treatment (particularly glibenclamide, known as glyburide in the USA and Canada) may result in beta cell degranulation and the induction of cell death [80, 81]. These potentially detrimental effects of sulfonylureas may serve to explain the relatively high rates of beta cell failure during sulfonylurea therapy in the a Diabetes Outcome Progression Trial (ADOPT), even though the rate of beta cell failure in sulfonylurea-treated patients was not increased in the UK Prospective Diabetes Study (UKPDS) [82, 83]. Insulinotropic agents with a shorter duration of action (e.g. repaglinide, nateglinide) or glucose-dependent properties (e.g. GLP-1, gastric inhibitory polypeptide) have been

Table 1 Therapeutic strategies with a potential direct effect on beta cell mass and turnover in different experimental models

\begin{tabular}{|c|c|c|c|c|}
\hline Treatment & $\begin{array}{l}\text { Effects on beta cell } \\
\text { turnover in vitro }\end{array}$ & $\begin{array}{l}\text { Effects on beta cell mass in } \\
\text { rodents in vivo }\end{array}$ & $\begin{array}{l}\text { Long-term effects on beta cell function } \\
\text { in humans }\end{array}$ & References \\
\hline \multicolumn{5}{|l|}{ Type 1 diabetes } \\
\hline Anti-CD3 antisera & No direct effect & $\begin{array}{l}\text { Prevention and reversal of } \\
\text { diabetes in NOD mice }\end{array}$ & $\begin{array}{l}\text { Preservation of beta cell function } \\
\text { in new-onset type } 1 \text { diabetes }\end{array}$ & {$[42,88]$} \\
\hline Cyclosporin & Beta cell apoptosis $\uparrow$ & $\begin{array}{l}\text { Prevention of diabetes in NOD } \\
\text { mice }\end{array}$ & $\begin{array}{l}\text { Preservation of beta cell function } \\
\text { in new-onset type } 1 \text { diabetes }\end{array}$ & [89] \\
\hline Nicotinamide & Beta cell apoptosis $\downarrow$ & $\begin{array}{l}\text { Prevention of diabetes in NOD } \\
\text { mice }\end{array}$ & $\begin{array}{l}\text { No prevention of type } 1 \text { diabetes } \\
\text { in high-risk subjects } \\
\text { No preservation of beta cell function } \\
\text { in new-onset type } 1 \text { diabetes }\end{array}$ & {$[90]$} \\
\hline $\begin{array}{l}\text { Potassium channel } \\
\text { openers (e.g. } \\
\text { diazoxide) }\end{array}$ & $\begin{array}{l}\text { Beta cell apoptosis } \downarrow \\
\text { Replenishment of insulin } \\
\text { granules }\end{array}$ & Not examined & $\begin{array}{l}\text { Preservation of beta cell function } \\
\text { in new-onset type } 1 \text { diabetes }\end{array}$ & {$[85,91]$} \\
\hline \multicolumn{5}{|l|}{ Type 2 diabetes } \\
\hline GLP-1 analogues & $\begin{array}{l}\text { Beta cell proliferation } \uparrow \\
\text { Beta cell apoptosis } \downarrow\end{array}$ & $\begin{array}{l}\text { Increase in beta cell mass in } \\
\text { diabetic rats and mice }\end{array}$ & $\begin{array}{l}\text { Stable glucose control over } 52 \text { weeks } \\
\text { of treatment } \\
\text { No prolongation of islet graft survival } \\
\text { after transplantation } \\
\text { No long-term studies available }\end{array}$ & $\begin{array}{r}{[68,84} \\
92,93]\end{array}$ \\
\hline DPP-4 inhibitors & $\begin{array}{l}\text { No direct effect (indirect } \\
\text { action via GLP-1 and } \\
\text { GIP) }\end{array}$ & $\begin{array}{l}\text { Increase in beta cell mass in } \\
\text { diabetic rats and mice }\end{array}$ & $\begin{array}{l}\text { Stable glucose control over } 52 \text { weeks } \\
\text { of treatment } \\
\text { No long-term studies available }\end{array}$ & {$[94,95]$} \\
\hline Metformin & $\begin{array}{l}\text { Beta cell apoptosis } \downarrow \\
\text { Markers of oxidative } \\
\text { stress } \downarrow\end{array}$ & $\begin{array}{l}\text { No direct effect on beta cell } \\
\text { mass }\end{array}$ & $\begin{array}{l}\text { Slow rate of deterioration of glucose } \\
\text { control (ADOPT trial) }\end{array}$ & $\begin{array}{l}{[22,83,} \\
96]\end{array}$ \\
\hline Glitazones & Beta cell apoptosis $\downarrow$ & $\begin{array}{l}\text { No direct effect on beta cell } \\
\text { mass }\end{array}$ & $\begin{array}{l}\text { Slow rate of deterioration of glucose } \\
\text { control (ADOPT trial) }\end{array}$ & $\begin{array}{l}{[83,96,} \\
97]\end{array}$ \\
\hline Sulfonylureas & Beta cell apoptosis $\uparrow$ & $\begin{array}{l}\text { Modest and transient increase in } \\
\text { beta cell mass (shown in one } \\
\text { study only) }\end{array}$ & $\begin{array}{l}\text { Progressive deterioration of glucose } \\
\text { control over prolonged treatment } \\
\text { periods in the ADOPT trial } \\
\text { No increased rate of deterioration } \\
\text { of beta cell function in the UKPDS }\end{array}$ & {$[80,82]$} \\
\hline $\begin{array}{r}\text { ACE inhibitors } \\
\text { (e.g. ramipril) }\end{array}$ & $\begin{array}{l}\text { Beta cell apoptosis } \downarrow \\
\text { Markers of oxidative } \\
\text { stress } \downarrow\end{array}$ & Increase in beta cell mass & $\begin{array}{l}\text { No significant effect on diabetes } \\
\text { incidence in randomised prospective } \\
\text { trials }\end{array}$ & {$[98,99]$} \\
\hline
\end{tabular}

ADOPT, a Diabetes Outcome Progression Trial; GIP, gastric inhibitory polypeptide; UKPDS, UK Prospective Diabetes Study 
shown to be less detrimental, or even protective, under in vitro conditions [81, 84]. While beta cell exhaustion may potentially accelerate the loss of beta cells in type 2 diabetes, induction of beta cell rest, i.e. the temporary inhibition of insulin secretion, appears to confer a certain degree of beta cell protection. In isolated human islets, temporary inhibition of insulin secretion using potassium channel openers has led to subsequent improvement of glucose-induced insulin secretion, increased islet insulin content, and inhibition of beta cell apoptosis [29, 85].

The mechanisms linking beta cell exhaustion to the induction of cell death have not been elucidated in detail, but many studies have suggested a key role of oxidative stress. There is accumulating evidence that beta cell insulin depletion leading to an increasing demand for proinsulin biosynthesis eventually results in the induction of ER stress, which in turn leads to the initiation of apoptosis. Consistent with this hypothesis, recent studies have found increased levels of ER stress markers in the islets of patients with type 2 diabetes [86].

From a clinical point of view, the simplest way of inducing beta cell rest is to reduce the peripheral insulin demand by either improving insulin sensitivity (e.g. through physical activity or pharmacologically, using metformin or glitazones) or by lowering blood glucose levels through the administration of exogenous insulin. In a prospective trial on patients with type 2 diabetes, induction of beta cell rest induced by bedtime administration of NPH insulin resulted in significant improvements in endogenous insulin secretion in response to glucose [75]. Likewise, in a study that compared insulin with glibenclamide over 2 years, recently diagnosed patients with type 2 diabetes treated with insulin exhibited a significantly greater endogenous insulin secretory response and a lower proinsulin:insulin ratio [87]. Nevertheless, as yet, there is no direct evidence for the induction of beta cell apoptosis by sulfonylurea drugs or for the preservation of beta cell mass by either metformin, glitazones or exogenous insulin in patients with type 2 diabetes in vivo.

A number of glucose-lowering agents (e.g. incretin mimetics, dipeptidylpeptidase 4 [DPP-4] inhibitors) have been suggested to prevent beta cell apoptosis, but their long-term effects on beta cell mass in patients with diabetes remain to be elucidated.

\section{Outlook}

In response to the increased recognition of the important role of beta cell mass in the development of diabetes interest has grown in targeting beta cell mass for the treatment for diabetes. A number of recent studies have suggested that beta cell mass might be restored by fostering endogenous beta cell replication, combined with concomitant inhibition of apoptosis. However, our current understanding of postnatal beta cell turnover is primarily based on experiments performed under in vitro conditions or in rodent models, the results of which are not fully generalisable to the situation in humans in vivo. Debate is ongoing as to the potential effects of various glucose-lowering treatments on beta cell death and proliferation, and some drugs have been proposed to accelerate beta cell loss (e.g. glibenclamide), whilst others have been suggested to be somewhat protective (e.g. GLP-1 receptor agonists, DPP-4 inhibitors). However, before any of these treatment regimens can be accepted as safely modulating beta cell turnover, changes in beta cell mass need to be demonstrated in patients with diabetes in vivo. In light of the absence of direct imaging methods to quantify beta cell mass in living humans, functional indices of insulin secretion derived from metabolic tests appear to provide the most meaningful estimates of beta cell mass. It is hoped that future long-term trials involving metabolic testing in patients with diabetes will determine changes in beta cell mass in response to various glucose-lowering treatment regimens. Such information will enable physicians to not only focus on glucose control, but perhaps also to modulate the natural progression of diabetes.

Acknowledgements The author is indebted to P. C. Butler for the critical discussion of this manuscript and helpful suggestions.

Duality of interest The author has received speaker's honoraria from the following drug companies: Aventis Pharma, NovoNordisk, Merck Sharp \& Dohme, Eli Lilly, Novartis.

\section{References}

1. Gepts W (1965) Pathologic anatomy of the pancreas in juvenile diabetes mellitus. Diabetes 14:619-663

2. Meier JJ, Bhushan A, Butler AE, Rizza RA, Butler PC (2005) Sustained beta cell apoptosis in patients with long-standing type 1 diabetes: indirect evidence for islet regeneration? Diabetologia 48:2221-2228

3. Butler AE, Janson J, Bonner-Weir S, Ritzel R, Rizza RA, Butler PC (2003) Beta-cell deficit and increased beta-cell apoptosis in humans with type 2 diabetes. Diabetes 52:102-110

4. Meier JJ, Bhushan A, Butler PC (2006) The potential for stem cell therapy in diabetes. Pediatr Res 59:65R-73R

5. Robertson RP (2000) Successful islet transplantation for patients with diabetes - fact or fantasy? N Engl J Med 343:289-290

6. Ryan EA, Paty BW, Senior PA et al (2005) Five-year follow-up after clinical islet transplantation. Diabetes 54:2060-2069

7. Robertson RP (2004) Islet transplantation as a treatment for diabetes - a work in progress. N Engl J Med 350:694-705

8. Meier JJ, Butler PC (2005) Insulin secretion. In: DeGroot LJ, Jameson JL (eds) Endocrinology, 5th edn. Elsevier Saunders, Philadelphia, pp 961-973

9. Reaven GM (1988) Banting lecture 1988. Role of insulin resistance in human disease. Diabetes 37:1595-1607 
10. Shaper AG, Wannamethee SG, Walker M (1997) Body weight: implications for the prevention of coronary heart disease, stroke, and diabetes mellitus in a cohort study of middle aged men. BMJ 314:1311-1317

11. Perley MJ, Kipnis DM (1967) Plasma insulin responses to oral and intravenous glucose: studies in normal and diabetic subjects. J Clin Invest 46:1954-1962

12. Ward WK, Bolgiano DC, McKnight B, Halter JB, Porte D Jr (1984) Diminished B cell secretory capacity in patients with noninsulindependent diabetes mellitus. J Clin Invest 74:1318-1328

13. Polonsky KS, Given BD, Hirsch LJ et al (1988) Abnormal patterns of insulin secretion in non-insulin-dependent diabetes mellitus. N Engl J Med 318:1231-1239

14. Gerich JE (1998) The genetic basis of type 2 diabetes mellitus: impaired insulin secretion versus impaired insulin sensitivity. Endocr Rev 19:491-503

15. Kruszynska YT, Home PD (1987) Insulin insensitivity in type 1 diabetes. Diabet Med 4:414-422

16. Kjems LL, Kirby BM, Welsh EM et al (2001) Decrease in betacell mass leads to impaired pulsatile insulin secretion, reduced postprandial hepatic insulin clearance, and relative hyperglucagonemia in the minipig. Diabetes 50:2001-2012

17. Kendall DM, Sutherland DE, Najarian JS, Goetz FC, Robertson RP (1990) Effects of hemipancreatectomy on insulin secretion and glucose tolerance in healthy humans. N Engl J Med 322:898-903

18. Meier JJ, Kjems LL, Veldhuis JD, Lefèbvre P, Butler PC (2006) Post prandial suppression of glucagon secretion depends on intact pulsatile insulin secretion: Further evidence for the intraislet insulin hypothesis. Diabetes 55:1051-1056

19. Matveyenko AV, Butler PC (2006) Beta-cell deficit due to increased apoptosis in the human islet amyloid polypeptide transgenic (HIP) rat recapitulates the metabolic defects present in type 2 diabetes. Diabetes 55:2106-2114

20. Pox C, Ritzel R, Busing M et al (2002) Combined pancreas and kidney transplantation in a lean type 2 diabetic patient. Effects on insulin secretion and sensitivity. Exp Clin Endocrinol Diabetes 110:420-424

21. Nath DS, Gruessner AC, Kandaswamy R, Gruessner RW, Sutherland DE, Humar A (2005) Outcomes of pancreas transplants for patients with type 2 diabetes mellitus. Clin Transplant 19:792-797

22. Marchetti P, Del Guerra S, Marselli L et al (2004) Pancreatic islets from type 2 diabetic patients have functional defects and increased apoptosis that are ameliorated by metformin. J Clin Endocrinol Metab 89:5535-5541

23. Robertson RP, Harmon J, Tran PO, Poitout V (2004) Beta-cell glucose toxicity, lipotoxicity, and chronic oxidative stress in type 2 diabetes. Diabetes 53(Suppl 1):S119-S124

24. Bonner-Weir S, Trent DF, Weir GC (1983) Partial pancreatectomy in the rat and subsequent defect in glucose-induced insulin release. J Clin Invest 71:1544-1553

25. Boden G, Chen X, Rosner J, Barton M (1995) Effects of a 48-h fat infusion on insulin secretion and glucose utilization. Diabetes 44:1239-1242

26. Janson J, Ashley RH, Harrison D, McIntyre S, Butler PC (1999) The mechanism of islet amyloid polypeptide toxicity is membrane disruption by intermediate-sized toxic amyloid particles. Diabetes 48:491-498

27. Robertson RP (2004) Chronic oxidative stress as a central mechanism for glucose toxicity in pancreatic islet beta cells in diabetes. J Biol Chem 279:42351-42354

28. Laybutt DR, Preston AM, Akerfeldt MC et al (2007) Endoplasmic reticulum stress contributes to beta cell apoptosis in type 2 diabetes. Diabetologia 50:752-763

29. Maedler K, Storling J, Sturis J et al (2004) Glucose- and interleukin-1 $\beta$-induced beta-cell apoptosis requires $\mathrm{Ca}^{2+}$ influx and extracellular signal-regulated kinase (ERK) $1 / 2$ activation and is prevented by a sulfonylurea receptor 1 /inwardly rectifying $\mathrm{K}^{+}$ channel 6.2 (SUR/Kir6.2) selective potassium channel opener in human islets. Diabetes 53:1706-1713

30. Ritzel RA, Butler AE, Rizza RA, Veldhuis JD, Butler PC (2006) Relationship between beta-cell mass and fasting blood glucose concentration in humans. Diabetes Care 29:717-718

31. Kloppel G, Drenck CR, Oberholzer M, Heitz PU (1984) Morphometric evidence for a striking B cell reduction at the clinical onset of type 1 diabetes. Virchows Arch A Pathol Anat Histopathol 403:441-452

32. Tsai EB, Sherry NA, Palmer JP, Herold KC (2006) The rise and fall of insulin secretion in type 1 diabetes mellitus. Diabetologia 49:261-270

33. Madsbad S (1983) Prevalence of residual B cell function and its metabolic consequences in type 1 (insulin-dependent) diabetes. Diabetologia 24:141-147

34. Pipeleers D, Ling Z (1992) Pancreatic beta cells in insulindependent diabetes. Diabetes Metab Rev 8:209-227

35. Butler AE, Galasso R, Meier JJ, Basu R, Rizza RA, Butler PC (2007) Modestly increased beta cell apoptosis but no increased beta cell replication in recent-onset type 1 diabetic patients who died of diabetic ketoacidosis. Diabetologia 50:2323-2331

36. Meier JJ, Lin JC, Butler AE, Galasso R, Martinez DS, Butler PC (2006) Direct evidence of attempted beta cell regeneration in an 89 -year old patient with recent onset type 1 diabetes. Diabetologia 49:1838-1844

37. The Diabetes Control and Complications Trial Research Group (1987) Effects of age, duration and treatment of insulin-dependent diabetes mellitus on residual beta-cell function: observations during eligibility testing for the Diabetes Control and Complications Trial (DCCT). J Clin Endocrinol Metab 65:30-36

38. Sreenan S, Pick AJ, Levisetti M, Baldwin AC, Pugh W, Polonsky KS (1999) Increased beta-cell proliferation and reduced mass before diabetes onset in the nonobese diabetic mouse. Diabetes 48:989-996

39. Lohr M, Kloppel G (1987) Residual insulin positivity and pancreatic atrophy in relation to duration of chronic type 1 (insulin-dependent) diabetes mellitus and microangiopathy. Diabetologia 30:757-762

40. Madsbad S, Krarup T, Reguer L, Faber OK, Binder C (1981) Effect of strict blood glucose control on residual B cell function in insulin-dependent diabetics. Diabetologia 20:530-534

41. The Diabetes Control and Complications Trial Research Group (1998) Effect of intensive therapy on residual beta-cell function in patients with type 1 diabetes in the diabetes control and complications trial. A randomized, controlled trial. Ann Intern Med 128:517-523

42. Chatenoud L, Thervet E, Primo J, Bach JF (1994) Anti-CD3 antibody induces long-term remission of overt autoimmunity in nonobese diabetic mice. Proc Natl Acad Sci USA 91:123-127

43. Pfeifer MA, Halter JB, Porte D Jr (1981) Insulin secretion in diabetes mellitus. Am J Med 70:579-588

44. Bruttomesso D, Pianta A, Mari A et al (1999) Restoration of early rise in plasma insulin levels improves the glucose tolerance of type 2 diabetic patients. Diabetes 48:99-105

45. Pørksen N, Nyholm B, Veldhuis JD, Butler PC, Schmitz O (1997) In humans at least $75 \%$ of insulin secretion arises from punctuated insulin secretory bursts. Am J Physiol 273:E908-E914

46. Matschinsky F, Liang Y, Kesavan P et al (1993) Glucokinase as pancreatic beta cell glucose sensor and diabetes gene. J Clin Invest 92:2092-2098

47. Zhou H, Tran PO, Yang S et al (2004) Regulation of alpha-cell function by the beta-cell during hypoglycemia in Wistar rats: the "switch-off" hypothesis. Diabetes 53:1482-1487

48. D'Amour KA, Bang AG, Eliazer S et al (2006) Production of pancreatic hormone-expressing endocrine cells from human embryonic stem cells. Nat Biotechnol 24:1392-1401 
49. Karlsson S, Scheurink AJ, Steffens AB, Ahren B (1994) Involvement of capsaicin-sensitive nerves in regulation of insulin secretion and glucose tolerance in conscious mice. Am J Physiol 267:R1071-R1077

50. Samols E, Stagner JI, Ewart RB, Marks V (1988) The order of islet microvascular cellular perfusion is B-A-D in the perfused rat pancreas. J Clin Invest 82:350-353

51. King AJ, Fernandes JR, Hollister-Lock J, Nienaber CE, BonnerWeir S, Weir GC (2007) Normal relationship of beta- and nonbeta-cells not needed for successful islet transplantation. Diabetes 56:2312-2318

52. Sorenson RL, Brelje TC (1997) Adaptation of islets of Langerhans to pregnancy: beta-cell growth, enhanced insulin secretion and the role of lactogenic hormones. Horm Metab Res 29:301-307

53. Kjos SL, Buchanan TA (1999) Gestational diabetes mellitus. N Engl J Med 341:1749-1756

54. Van Assche FA, Aerts L, De Prins F (1978) A morphological study of the endocrine pancreas in human pregnancy. Br J Obstet Gynaecol 85:818-820

55. Hellerstrom C, Swenne I (1991) Functional maturation and proliferation of fetal pancreatic beta-cells. Diabetes 40(Suppl 2):89-93

56. Scaglia L, Cahill CJ, Finegood DT, Bonner-Weir S (1997) Apoptosis participates in the remodeling of the endocrine pancreas in the neonatal rat. Endocrinology 138:1736-1741

57. Dor Y, Brown J, Martinez OI, Melton DA (2004) Adult pancreatic beta-cells are formed by self-duplication rather than stem-cell differentiation. Nature 429:41-46

58. Butler AE, Janson J, Soeller WC, Butler PC (2003) Increased betacell apoptosis prevents adaptive increase in beta-cell mass in mouse model of type 2 diabetes: evidence for role of islet amyloid formation rather than direct action of amyloid. Diabetes 52:2304-2314

59. Teta M, Long SY, Wartschow LM, Rankin MM, Kushner JA (2005) Very slow turnover of $\beta$-cells in aged adult mice. Diabetes $54: 2557-2567$

60. Finegood DT, Scaglia L, Bonner-Weir S (1995) Dynamics of betacell mass in the growing rat pancreas. Estimation with a simple mathematical model. Diabetes 44:249-256

61. Meier JJ, Butler AE, Galasso R, Butler PC (2006) Hyperinsulinemic hypoglycemia after gastric bypass surgery is not accompanied by islet hyperplasia or increased beta-cell turnover. Diabetes Care 29:1554-1559

62. Meier JJ, Butler AE, Galasso R, Rizza RA, Butler PC (2006) Increased islet beta cell replication adjacent to intrapancreatic gastrinomas in humans. Diabetologia 48:2689-2696

63. Bonner-Weir S, Baxter LA, Schuppin GT, Smith FE (1993) A second pathway for regeneration of adult exocrine and endocrine pancreas. A possible recapitulation of embryonic development. Diabetes 42:1715-1720

64. Bouwens L, Pipeleers DG (1998) Extra-insular beta cells associated with ductules are frequent in adult human pancreas. Diabetologia 41:629-633

65. Bonner-Weir S (2001) Beta-cell turnover: its assessment and implications. Diabetes 50(Suppl 1):S20-S24

66. Peshavaria M, Larmie BL, Lausier J et al (2006) Regulation of pancreatic beta-cell regeneration in the normoglycemic $60 \%$ partial-pancreatectomy mouse. Diabetes 55:3289-3298

67. Bonner-Weir S, Deery D, Leahy JL, Weir GC (1989) Compensatory growth of pancreatic beta-cells in adult rats after short-term glucose infusion. Diabetes 38:49-53

68. Xu G, Stoffers DA, Habener JF, Bonner-Weir S (1999) Exendin-4 stimulates both beta-cell replication and neogenesis, resulting in increased beta-cell mass and improved glucose tolerance in diabetic rats. Diabetes 48:2270-2276

69. Bouwens L, Lu WG, De Krijger R (1997) Proliferation and differentiation in the human fetal endocrine pancreas. Diabetologia 40:398-404
70. Chen S, Turner SM, Tsang E et al (2007) Measurement of pancreatic islet cell proliferation by heavy water labeling. Am J Physiol Endocrinol Metab 293:E1459-E1464

71. Malaisse WJ (2001) On the track to the beta-cell. Diabetologia 44:393-406

72. Polonsky KS, Given BD, Hirsch L et al (1988) Quantitative study of insulin secretion and clearance in normal and obese subjects. $\mathrm{J}$ Clin Invest 81:435-441

73. Fehse F, Trautmann M, Holst JJ et al (2005) Exenatide augments first- and second-phase insulin secretion in response to intravenous glucose in subjects with type 2 diabetes. J Clin Endocrinol Metab 90:5991-5997

74. Laedtke T, Kjems L, Porksen N et al (2000) Overnight inhibition of insulin secretion restores pulsatility and proinsulin/insulin ratio in type 2 diabetes. Am J Physiol 279:E520-E528

75. Cusi K, Cunningham GR, Comstock JP (1995) Safety and efficacy of normalizing fasting glucose with bedtime NPH insulin alone in NIDDM. Diabetes Care 18:843-851

76. Meier JJ, Veldhuis JD, Butler PC (2005) Pulsatile insulin secretion dictates systemic insulin delivery by regulating hepatic insulin extraction in humans. Diabetes 54:1649-1656

77. Robertson RP (2007) Estimation of beta-cell mass by metabolic tests: necessary, but how sufficient? Diabetes 56:2420-2424

78. Teuscher AU, Kendall DM, Smets YF, Leone JP, Sutherland DE, Robertson RP (1998) Successful islet autotransplantation in humans: functional insulin secretory reserve as an estimate of surviving islet cell mass. Diabetes 47:324-330

79. Ryan EA, Lakey JR, Paty BW et al (2002) Successful islet transplantation: continued insulin reserve provides long-term glycemic control. Diabetes 51:2148-2157

80. Efanova IB, Zaitsev SV, Zhivotovsky B et al (1998) Glucose and tolbutamide induce apoptosis in pancreatic beta-cells. A process dependent on intracellular $\mathrm{Ca}^{2+}$ concentration. J Biol Chem 273:33501-33507

81. Maedler K, Carr RD, Bosco D, Zuellig RA, Berney T, Donath MY (2005) Sulfonylurea induced beta-cell apoptosis in cultured human islets. J Clin Endocrinol Metab 90:501-506

82. Matthews DR, Cull CA, Stratton IM, Holman RR, Turner RC (1998) UKPDS 26: sulphonylurea failure in non-insulin-dependent diabetic patients over six years. UK Prospective Diabetes Study (UKPDS) Group. Diabet Med 15:297-303

83. Kahn SE, Haffner SM, Heise MA et al (2006) Glycemic durability of rosiglitazone, metformin, or glyburide monotherapy. N Engl J Med 355:2427-2443

84. Farilla L, Bulotta A, Hirshberg B et al (2003) Glucagon-like peptide 1 inhibits cell apoptosis and improves glucose responsiveness of freshly isolated human islets. Endocrinology 144:5149-5158

85. Ritzel RA, Hansen JB, Veldhuis JD, Butler PC (2004) Induction of $\beta$-cell rest by a Kir6.2/SUR1-selective $\mathrm{K}_{\mathrm{ATP}}$-channel opener preserves $\beta$-cell insulin stores and insulin secretion in human islets cultured at high $(11 \mathrm{mM})$ glucose. J Clin Endocrinol Metab 89:795-805

86. Huang CJ, Lin CY, Haataja L et al (2007) High expression rates of human islet amyloid polypeptide induce endoplasmic reticulum stress mediated beta-cell apoptosis, a characteristic of humans with type 2 but not type 1 diabetes. Diabetes 56:2016-2027

87. Alvarsson M, Sundkvist G, Lager I et al (2003) Beneficial effects of insulin versus sulphonylurea on insulin secretion and metabolic control in recently diagnosed type 2 diabetic patients. Diabetes Care 26:2231-2237

88. Herold KC, Hagopian W, Auger JA et al (2002) Anti-CD3 monoclonal antibody in new-onset type 1 diabetes mellitus. N Engl J Med 346:1692-1698

89. Carel JC, Boitard C, Eisenbarth G, Bach JF, Bougneres PF (1996) Cyclosporine delays but does not prevent clinical onset in glucose intolerant pre-type 1 diabetic children. J Autoimmun 9:739-745 
90. Hoorens A, Pipeleers D (1999) Nicotinamide protects human beta cells against chemically-induced necrosis, but not against cytokine-induced apoptosis. Diabetologia 42:55-59

91. Bjork E, Berne C, Kampe O, Wibell L, Oskarsson P, Karlsson FA (1996) Diazoxide treatment at onset preserves residual insulin secretion in adults with autoimmune diabetes. Diabetes 45:1427-1430

92. Nauck MA, Duran S, Kim D et al (2007) A comparison of twicedaily exenatide and biphasic insulin aspart in patients with type 2 diabetes who were suboptimally controlled with sulfonylurea and metformin: a non-inferiority study. Diabetologia 50:259-267

93. Ghofaili KA, Fung M, Ao Z et al (2007) Effect of exenatide on beta cell function after islet transplantation in type 1 diabetes. Transplantation 83:24-28

94. Pospisilik JA, Martin J, Doty T et al (2003) Dipeptidyl peptidase IV inhibitor treatment stimulates beta-cell survival and islet neogenesis in streptozotocin-induced diabetic rats. Diabetes 52:741-750

95. Ahren B, Gomis R, Standl E, Mills D, Schweizer A (2004) Twelve- and 52-week efficacy of the dipeptidyl peptidase IV inhibitor LAF237 in metformin-treated patients with type 2 diabetes. Diabetes Care 27:2874-2880

96. Hull RL, Shen ZP, Watts MR et al (2005) Long-term treatment with rosiglitazone and metformin reduces the extent of, but does not prevent, islet amyloid deposition in mice expressing the gene for human islet amyloid polypeptide. Diabetes 54:2235-2244

97. Lin CY, Gurlo T, Haataja L, Hsueh WA, Butler PC (2005) Activation of peroxisome proliferator-activated receptor-gamma by rosiglitazone protects human islet cells against human islet amyloid polypeptide toxicity by a phosphatidylinositol 3'-kinasedependent pathway. J Clin Endocrinol Metab 90:6678-6686

98. Lupi R, Del Guerra S, Bugliani M et al (2006) The direct effects of the angiotensin-converting enzyme inhibitors, zofenoprilat and enalaprilat, on isolated human pancreatic islets. Eur J Endocrinol 154:355-361

99. Gerstein HC, Yusuf S, Bosch J et al (2006) Effect of rosiglitazone on the frequency of diabetes in patients with impaired glucose tolerance or impaired fasting glucose: a randomised controlled trial. Lancet 368:1096-1105 